University of New Hampshire

University of New Hampshire Scholars' Repository

Law Faculty Scholarship

University of New Hampshire - Franklin Pierce

School of Law

$1-1-2011$

\title{
Will Work': The Role of Intellectual Property in Transitional Economies - From Coal to Content
}

Megan M. Carpenter

University of New Hampshire School of Law, megan.carpenter@law.unh.edu

Follow this and additional works at: https://scholars.unh.edu/law_facpub

Part of the Economics Commons, Entrepreneurial and Small Business Operations Commons, Law

Commons, and the Technology and Innovation Commons

\section{Comments}

Available at http://www.worldcat.org/oclc/869596478

\section{Recommended Citation}

Megan M. Carpenter, 'Will Work': The Role of Intellectual Property in Transitional Economies -- From Coal to Content, in LAW, CREATIVITY, AND ENTREPRENEURSHIP (Shubha Ghosh \& Robin Paul Malloy, eds., 2011).

This Book Chapter is brought to you for free and open access by the University of New Hampshire - Franklin Pierce School of Law at University of New Hampshire Scholars' Repository. It has been accepted for inclusion in Law Faculty Scholarship by an authorized administrator of University of New Hampshire Scholars' Repository. For more information, please contact sue.zago@law.unh.edu. 


\section{4. 'Will work': the role of intellectual property in transitional economies - from coal to content}

Megan M. Carpenter

As a child in the mountains of West Virginia, I rode with my grandmother to drop off my aunt and uncles at the bus stop. ${ }^{1}$ In the morning, sitting in her Jeep with the herringbone seats of the 1970s, pancake syrup in the corners of my mouth, the soundtrack of our trip was the morning mine report on the radio. 'Loveridge, will work. Blacksville, will work. Sentinel, will work.' The mine reports were at that time, for me, the rhythm of morning. I heard them underneath the tones of conversation, and occasionally in my head as I went through the day, playing with dolls, running down our country road. Even now, it is sometimes the rhythm of the mine reports that comes back to me as I knead bread. It is morning. It is routine. It is home.

I didn't understand then, but I remember holding my breath for a moment and feeling a tiny sliver of relief every time I heard the words 'will work'. Hard work is a cornerstone of worth, and working is something we do, with our minds and our bodies and our hands. (Later, I would learn that 'he sure is a hard worker' was the highest compliment a prospective boyfriend could receive.) I didn't know why mines wouldn't work, but working always seemed good and sure, an understanding I had even at the age of five or six. Loveridge. Will Work. Blacksville. Will Work. Sentinel. Will Work.

I went to school with the sons and daughters of miners and manufacturers, with the children of people who worked underground, and, when above ground, for Philips Electric and Alcan. My grandfather and his brother made cardboard boxes for Beech Nut. We all went to school together. We lived in the country. We had long and curvy bus rides, during which we tried unsuccessfully to keep our hands steady to write missives on fogged windows. The children of miners often had reflective stickers to put on their notebooks, stickers that were destined for hardhats but which found their way on to folders and backpacks. Sometimes 
they reflected light, miles underground in the inner chambers of a school desk.

I did not think much about West Virginia's economy, although I understood that we were a poor state. I understood that coal mining was our economic pride and joy. I coveted the small figurines of bears and deer carved out of coal I found at general stores and gas stations when we went camping. I collected coal I found along the train tracks across the river. I looked forward to the annual Coal Festival. Coal has sat at the heart of the Appalachian people (and sometimes our lungs), just as it sits at the heart of our land.

While coal production has stayed steady, however, coal mining jobs have decreased dramatically. The same out of state interests which people once forgave for extracting resources and funnelling profits back out of state, in the name of jobs and work (it is better to will work, than won't work, surely), began not to need people so much anymore. The mines began sending work out of state in the 1950s. Increasingly, mining operations became mechanized, so miners became less necessary to the process. Over time, the radio no longer reported as often will work. Eventually, the morning reports stopped altogether. There are now about as many miners underground in West Virginia as people who work for Wal-Mart. ${ }^{2}$ But coal production remains steady, and through mechanized mountaintop removal mining, the people of Appalachia have now lost not only many thousands of jobs, but approximately 500000 acres of mountain lands and 1200 miles of rivers and streams - more than 700 miles of those rivers and streams have been buried entirely. ${ }^{3}$

Appalachian people know not just the coal inside but the art of those mountains - the woodcrafting, the ghost stories, the recipes, the dried herbs, the homemade wine. My grandfather got in trouble at the age of 14 for making dandelion wine in his basement. (To his credit, he didn't get in trouble until it began exploding violently in the house.) We grew up playing house under the complex caverns of rhododendron; we made wreaths from grapevine down the road. Our music is soul music, the fiddles are blood, coursing, and the banjo strings are plucks of nostalgia. Our arts are inexplicably tied with our culture, and we Appalachians have always known that.

I grew up on the same road as cousins and grandparents, and neighbors like family. It doesn't take a village to raise a child, I would tell Hillary Clinton, just a small country road, nestled between the rhododendron and the river. I also grew up knowing one unassailable fact: I would have to leave West Virginia if I wanted to find a 'real' job. If I wanted will work instead of won't work. My friends and I lamented this. We lamented this because we loved our state, with blood like fiddles, with nostalgia like 
banjos. But the opportunities we knew were few. The lack of economic opportunity is reflected in census statistics: West Virginia has the second smallest population growth of any state, and the oldest median population in the entire United States. ${ }^{4}$

My grandmother would tell me of the time when her father was the Sheriff, and they lived downtown in the Sheriff's residence, and people walked up and down the street in the evenings, greeting each other and shopping, bustling and busying. In my own history, the beautiful downtown buildings of my town remained (beautiful but) empty, but I do remember the main avenue, the stately old homes lining the way to and from the center of town. As they ceased to be residences, I took dance classes in one, went to the eye doctor in another and snuck into a tiny fortune teller's booth in a third. Those houses are torn down now and there are fast food restaurants, a chain pharmacy and even a car wash(!), and that is economic development at work ...

This story is not unique to West Virginia. It is the story of so many places across the United States, places that have historically been steeped in economies of mining and manufacturing, industries that not only have damaged parts of the landscape - through extracting resources, pollution or harmful industry practice - but also are no longer as viable as they once were. This is the modern American story. Old economy sources are drying up, or becoming obsolete, and communities across the country must transition to a new economy. Alan Greenspan has noted for years that our economy is primarily conceptual in nature now, based on content and information rather than physicality. ${ }^{5}$ But encouraging transition is more easily said than done; how do we move from industry to information, from coal to content? The key to our economic future lies in a successful transition from the old economy to the new.

Support for, and development of, intellectual property is an essential element of this transition. Intellectual property is the fruit of human creativity and invention, and an economy based in information and content is, simply, an economy built on intellectual property. Intellectual property is unique as a driver of economic development, in part because it is not as geographically limiting as traditional economic resources are and can be as available to people in rural communities as to those in urban areas. The new economy thus presents opportunities that were formerly impossible; areas isolated by geography, by their rural character or by other socioeconomic demographics are no longer economically isolated. Rather, the new economy, the global information economy, is potentially open and accessible to all. For economies in transition, therefore, it is vital to work out how to support the growth and development of intellectual property through both legal and economic frameworks. 


\section{THE UNIVERSITY COMMUNITY}

Universities have historically been, and continue to be, a driving vehicle to encourage entrepreneurship. The spirit of entrepreneurship is very much definitional of the American spirit, and universities have long sat at its core. While technology transfer programs and research divisions of academic institutions are often thought of as products of modern innovation, the fact remains that universities have partnered with government entities in the interest of research and development throughout much of the economic and developmental history of the United States. The creation of land-grant universities through the Morrill Act, ${ }^{6}$ the Hatch Act, ${ }^{7}$ the Adams Act, ${ }^{8}$ and the Smith-Lever Act ${ }^{9}$ serves as a quintessential example of the federal government creating links between education and research and development, as do post-World War II programs of federal investment in university R\&D, often involving collaboration between government entities, the academy, and private industry. ${ }^{10}$ Universities both public and private have further been a part of state and federal economic development activity. ${ }^{11}$

Government and university involvement in economic development has often grown out of areas where the market proves inadequate as the sole vehicle driving innovation. In an economy now focused on information and content, federal policies have shifted accordingly, and are directed toward basic research and development in technology and science at universities, as well as technology transfer and commercialization. Feller attributes this shift, in part, to an increased recognition that new technologies have first-mover advantages in the global marketplace, and that R\&D departments at universities are uniquely positioned to address rapid development of those technologies and their (sometimes even more rapid) subsequent obsolescence. ${ }^{12}$ Modern technology often moves more quickly than the market infrastructure, a problem that is only complicated, if not compounded, by increased globalization. Additionally, while technologies are rapidly evolving, those technologies become even more heavily dependent on complex R\&D which is often too much for a single private entity to take on, particularly in the context of entrepreneurial start-up firms. ${ }^{13}$ By linking private business entities with university R\&D, those entities can focus on business development and shorter term projects while benefitting from the breadth and depth of university resources.

Converting the fruits of university R\&D to viable products in the marketplace has proven to be a unique challenge, and federal investment has shifted once again to address this bottleneck in the independent marketplace. Since the 1980s, government involvement has focused on improving technology transfer and commercialization of university R\&D. ${ }^{14}$ Under 
the Bayh Dole Act, ${ }^{15}$ passed by Congress in the 1980 s, universities and businesses can retain intellectual property rights to the results of federally funded research and development. The Bayh Dole Act has dramatically improved the nation's ability to move ideas from research and development to commerce, and to enhance the return on a substantial taxpayer investment. While some federal agencies, including the Department of Defense, the National Science Foundation and the National Institutes of Health, had previously allowed universities to retain patent rights to their inventions, other agencies, such as the National Aeronautics and Space Administration, the Department of Agriculture and the Department of Energy, had long-established 'title in the government' policies, with licenses on a non-exclusive, royalty-free basis (or with limited exclusivity and royalties), focusing more on dedicating the inventions to the public than supporting commercialization of innovation. ${ }^{16}$

Given relatively less attention, but as important for the landscape, is the Stevenson-Wydler Act, ${ }^{17}$ which was passed a couple of months before Bayh-Dole. The Stevenson-Wydler Act lends statutory support for the principle that the government should ensure the full utilization of its investment in R\&D, including transferring federally owned or federally originated technologies to the private sector and to state and local governments. ${ }^{18}$ Under the Act, agencies were required to devote a percentage of their R\&D budgets to technology transfer, and to establish Offices of Research and Technology Applications at their laboratories. ${ }^{19}$ Other federal acts, such as the National Cooperative Research Act $^{20}$ and the Omnibus Trade and Competitiveness $\mathrm{Act}^{21}$ (as well as a host of corresponding legislation by states) combine to create a legislative fabric of support for technology transfer. As a result of this supporting legislation, a spotlight has been shone on universities as sources of technological development and innovation.

Even federal programs that are not directly impacting university technology transfer involve universities in significant ways. The Small Business Innovation Research program (SBIR), for example, requires federal government agencies that fund innovation research to set aside 2.5 per cent of their budgets for contracts with small businesses. ${ }^{22}$ The early-stage capital generated from this program is approximately equivalent to two-thirds the size of the entire venture capital industry. ${ }^{23}$ Often businesses that have been awarded SBIR grants enter into subcontracting relationships with universities, and, as a result, Shane notes that the grants 'increased the formation of biotechnology companies, by motivating academic researchers to undertake more commercial activity, by providing a demonstration effect to other scientists and engineers, and by making more capital available to spin-off companies. ${ }^{24}$ The Advanced Technology Program (ATP) 
has similarly increased university spin-offs, by bridging a funding gap that supported spin-offs from concept to proof of concept to prototype, allowing them an infrastructure of support to develop the business sufficiently before seeking private sector capital. ${ }^{25}$

Technology transfer programs at universities often serve as an impetus for encouraging entrepreneurship through spin-off companies and start-up firms. And, in fact, these programs across the country demonstrate a record of commercial successes, including the creation of entirely new technology-based industries. There is a paucity of recent, comprehensive research on the impact of university spin-offs on economic development, but it is estimated that the direct economic impact of university spin-off companies from 1980 to 1999 was US $\$ 33.5$ billion, or roughly US $\$ 10$ million per company founded. ${ }^{26}$ In addition, during that time university spin-offs created approximately 280000 jobs, exceeding both the rate of the average new company in the United States and the average rate of job creation by established licensees of university inventions. ${ }^{27}$

University created spin-offs are often particularly productive because university research is frequently either too early in a product cycle, or too far ahead of the market, to be developed otherwise ${ }^{28}$ Large companies often focus their sales and marketing to an established customer base, not on disruptive technologies that would foster the most innovation. University spin-offs, on the other hand, focus their energies on different, less certain types of inventions, leading to the commercialization of products and technologies that would not otherwise be in the market. ${ }^{29}$ Massachusetts Institute of Technology (MIT), with an enormously successful technology transfer program, has had a remarkable effect on the Massachusetts economy. The estimated 6900 alumni-created companies have generated revenue totalling US\$164 billion in worldwide sales. ${ }^{30}$ While fewer than 10 per cent of entering freshmen are from the state, approximately 38 per cent of alumni-created businesses are located in Massachusetts. ${ }^{31}$ Revenue from MIT spin-offs span from semiconductors of Fairchild, to Intel's integrated circuits, to Genetech biotechnology; revenue from companies created by MIT alumni equals at least the seventeenth largest economy in the world..$^{32}$

Spin-offs can have a positive effect from both within and without. Certainly in a university environment, spin-offs can encourage the growth and retention of entrepreneurial faculty, as well as present opportunities for a university to share in the growth through equity or royalties. Outside the university environment, they can be an engine for regional economic growth and job creation in a diversified, 'new economy', making an area less dependent on old economy resources, and can attract satellite businesses and other, related technology companies. The Research Triangle in 
North Carolina is a prime example of this type of economic development, as is the Route 128 corridor around Boston, which has itself become a symbol for high-tech development.

In addition, there is a direct correlation between government financial support of university R\&D and the number of spin-off companies and technology licensors. The federal government currently contributes US\$30 billion to fund research at US research universities, which is approximately 60 per cent of all research conducted at those universities. ${ }^{33}$

Technology transfer programs can be particularly important in small or medium sized regions, where research institutions play an important role in fostering and supporting technology-based development through the generation of commercially viable ideas, training sophisticated workers and problem solving for local companies. The university itself is a vital economic stimulus, providing an environment for the development of innovative research that would be too risky for the private sector. The presence of strong R\&D departments within a university environment can fit well into the mission for the university as a safe space to challenge ideas, and to explore, develop, and test them - as T.S. Eliot might describe it, "time for a hundred visions and revisions, before the taking of a toast and tea'. ${ }^{34}$

The university setting has historically been a bastion of innovation in myriad ways, and has become almost a clichéd symbol of personal intellectual growth in the community, from political activism to expansive theory to art. The Dean of the Creative Arts College at a university where I once lectured came to talk to the law faculty at a brown-bag lunch, which was structured as a forum for interdisciplinary exchange of ideas. At the lunch, we discussed the role of the university in the community. He told us about an exhibit of works by Masters of Fine Arts (MFA) students, some of which were photographs containing male nudity. The exhibition was hung at the end of the school year, and was consequently showing when the state-sponsored public theatre began use of the theatre for its summer stock program. The Dean was discussing the disparate roles that must be balanced in such a situation, and whether or not it is possible to seek some middle ground. Should the university evaluate and remove potentially offensive exhibits during the summer public theatre program? Should it censor the works exhibited by students at certain times of the year? As we began to discuss the issue, one of my colleagues stood up and remarked, 'Where else other than a university will students be able to push the envelope? If the university isn't a safe space for students to test the bounds of their study, where is?' As he sat down, he added, 'I'd rather see potentially objectionable photographs at the University, even if they were terrible quality, than I would the 40000 th mediocre production of 
"Oklahoma".' The room was filled with laughter at that point, but my colleague made a good point: the university environment is precisely the place where substantial innovation can occur. Because innovators at a university - whether in the area of nude photography, or engineering, or health sciences - are not beholden to a commercial market, research and development can occur which would not in an otherwise strictly marketdriven economy.

Perhaps the most well-known entrepreneurial story, nearly mythological in today's technological culture, is one that, strikingly, did not utilize university R\&D channels at all. Steve Jobs and Steve Wozniak, in fact, dropped out of college and then invented the first personal computer in a garage. ${ }^{35}$ They sold their first 50 machines of the Apple Is to a company called The Byte Shop, in Mountain View, California. ${ }^{36}$ Jobs encouraged programmers to create applications for the computers, and in a fairly short period of time there were 15000 applications for the Apple. ${ }^{37}$ The company obtained US\$600000 in venture capital funding, which then paved the way for its legendary success. ${ }^{38}$ In 1979, Steve Wozniak was granted a patent for a microcomputer, and the icon-rich interface navigable by a mouse was not far behind. ${ }^{39}$ The rest, we might say, is a big byte of innovation history.

Maybe this exposes a certain bias as an educator, but we want to make sure that we have an educational system in universities that values intellectual property such that Jobs and Wozniak are better off in school than out of school. And developments over the last three decades have helped to ground that aspiration in some kind of reality. Through universitysponsored small business incubators, technology transfer programs with supporting federal legislation, entrepreneurship programs and partnerships with private industry, universities are building their own garages to experiment, to engage in research and development to create and exploit intellectual properties. And it is essential that universities take on this role, for they are able to do so uniquely, with the goals of research and service and academic freedom being front and center, rather than market survival and profit.

\section{STATE LEGISLATION AND PROGRAMS}

In addition to (and sometimes as an intrinsic part of) university research and development, entrepreneurship is key to innovation. Economic strength in a technology-rich information economy requires start-ups because large companies are often reluctant to pioneer radical innovations. Furthermore, most net new jobs in the United States come from 
fast-growing small businesses. One way to foster innovation and entrepreneurship is through the university system. But there are other essential components that work both with university-driven programs and outside those programs to support entrepreneurship in transitional economies. State legislation and programs can serve as an impetus for innovation and encourage contributions to the creative economy.

States can pass legislation that encourages a creative economy and enables them to take an active role in the transition between old and new economic resources. This can be done in a variety of ways - one significant way that states have begun to promote economic development through creativity is through film incentive programs. Since the passage of the New Mexico film incentive program in 2002, for example, 115 major film productions have taken advantage of it..$^{40}$ In 2007 alone, 30 films were produced, generating US\$253 million of spending benefitting the New Mexican economy. ${ }^{41}$ In 2007, 3829 jobs were created directly and indirectly as a result of the industry..$^{42}$ Film related capital expenditures and tourism resulted in a total impact of 3829 jobs, with a state tax impact of over US\$44 million..$^{43}$

Film incentive programs are effective in influencing filmmakers; while major recent major motion pictures 'No Country for Old Men', 'The Great Debaters' and 'W.' were set in the state of Texas, they were all filmed in either New Mexico or Louisiana, which have geographic areas that look similar to Texas but which offer much more aggressive economic incentives ${ }^{44}$ By way of illustration, the Louisiana film incentive program gives investors a 25 per cent tax credit against the amount of the investment. ${ }^{45}$ An additional 10 per cent of total payroll spent on employing Louisiana residents is available to further qualifying film productions ${ }^{46}$ Due to the effectiveness of these programs, which are often designed to draw out-of-state producers and encourage local productions, more than two-thirds of US states have now passed legislation to encourage the creative economy, and to prevent 'runaway productions', a term used to describe films intended to be set in a certain geographic area that are shot elsewhere. ${ }^{47}$

For both of these reasons, Texas recently passed the Moving Image Industry Incentive Program (MIIIP) ${ }^{48}$ The MIIIP covers film, television and multimedia productions (including video games) and offers investors the ability to receive a return of up to 5 per cent of their investment to the extent that investment is comprised of money spent in Texas, including wages ${ }^{49}$ Film productions in outlying film production areas (specifically, areas other than Austin and Dallas) are given an additional incentive of 1.25 per cent, for a possible total return to investors per film of 6.25 per cent. $^{50}$ 
Incentive programs appear to be extremely successful in generating economic development in the states that have them, which has a negative economic consequence to states that do not have such programs. Legislation in West Virginia has recently created the West Virginia Film Industry Investment program, and, while the allotted US\$10 million budget is relatively small, two feature films and a multi-episode television program are beginning inaugural production under the program this year. ${ }^{51}$ Accountants in Florida estimate that the incentive program in that state resulted in a seven-fold return to local businesses on state dollars spent for the program. ${ }^{52}$ Prior to the passage of the Louisiana bill, for example, that state averaged between US $\$ 20$ million and US\$30 million per year in film and television income. ${ }^{53}$ In contrast, in 2005, despite Hurricane Katrina, after the passage of the program Louisiana saw an income of US\$550 million in film productions. ${ }^{54}$ Texas, on the other hand, without an incentive program, experienced a decrease that year of US\$80 million. ${ }^{55}$ This reduction is in contrast to figures in previous years, which typically were in the range of US\$300 million. ${ }^{56}$

Since the passage of the MIIIP, Texas has seen an increase in film production, particularly out-of-state film production. Within approximately the first year of the program, Texas had 138 applications filed, 25 of which were from outside the state, altogether totalling US\$148 million spent inside the state's borders. ${ }^{57}$ Additionally, Texas has become third in the United States in terms of the number of publishers and developers of video games. ${ }^{58}$ Since the passage of the MIIIP, more than a dozen applications have been filed by video game companies, and 180 permanent jobs have been created as a result. ${ }^{59}$ In fact, the sector of the creative economy focused on interactive entertainment in Texas spent approximately US $\$ 177$ million in the state in 2008 alone. ${ }^{60}$ While Texas has seen concrete results from the program, the increase in in-state film production is much smaller than it has been in other states with stronger incentive programs. Texas has lost more than one film set in Texas to Michigan, for example, where the geography is dissimilar to Texas, but where there is a 40 per cent tax credit. ${ }^{61}$ In addition, the Louisiana incentive program, for example, still exceeds the Texas incentives by nearly 20 per cent. (To complicate matters further, strong incentive programs are made more difficult in Texas, because there is no state income tax to provide a source of credit.) Legislation that directly supports creativity and entrepreneurship has the effect of benefitting a state's creative economy in indirect ways, as well, with positive effects on basic elements of the community such as restaurants and hotels.

State and federal programs to encourage entrepreneurship on a broader scale play a significant role in the transition from old to new economy. 
Some of these programs include organizations that assist small businesses with development, including resources and financial assistance, as well as training opportunities. Often these programs are the first to go when times are tough, in favor of the largest company a state can find to come in and hire a few dozen people, but such decisions are short-sighted and do not take into consideration either the importance of helping people to generate wealth and industry from within, or the tendency of those large companies to take their profits back out of the state with them.

This phenomenon is often painfully visible in smaller states whose economies were previously heavily based in traditional industry. West Virginia illustrates this phenomenon, in fact, with disturbing results. In that state, programs designed to encourage development in the high-tech sector through entrepreneurship and creativity have been drastically cut over the last few years, and resources shifted (or regressed) to support old economy interests. The West Virginia High Technology Consortium Foundation (WVHTCF), which has sat at the center of the push toward high-tech economic development in that state, has seen its budget slashed over the last couple of years. The WVHTCF is structured to engage first-hand in research and development but also, importantly, to help with small business development, including resources and financial assistance, as well as educational and training opportunities. ${ }^{62}$ One organization that the Foundation helped to create was the Institute for Scientific Research, an organization that provides cutting edge research in software engineering. ${ }^{63}$

The goal of organizations and incubators across the country, of which the WVHTCF is but one example, is not to perpetuate themselves, but to enable citizens to participate in the high-tech information economy. As a result, they are often not profitable per se, but are the behind-the-scenes force enabling to the extent possible equality of economic opportunity - the wind beneath the wings, if you will, of entrepreneurship. And yet, despite the foresight of politicians and non-profit advocates who create these organizations - West Virginia's senior Congressman Alan Mollohan, in these examples - these are often the organizations that receive the steepest cuts in tough times, arguably when they are needed most. In addition to the cuts experienced by the WVHTCF, other organizations similarly important in that state's effort to promote entrepreneurship and creativity, albeit in more indirect ways, have received similarly severe budget cuts. MountainMade, for example, is an organization that helps support local artisans to make a living with their art, by gathering individual artists who would be unlikely to find an economic opportunity for their work together under one umbrella, both online and in a bricks-and-mortar gallery and studio. ${ }^{64}$ The Canaan Valley Institute was created to assist communities in solving wastewater treatment and watershed problems, including 
flooding and erosion of the riverbanks, one of West Virginia's most valuable resources for tourism. ${ }^{65}$ And the Vandalia Heritage Foundation and Vandalia Redevelopment Corporation are particularly designed to bring together economic development experts with preservationists to counsel local communities in redeveloping their structures for new and productive uses. ${ }^{66}$ Because of the resources they provide, support for organizations like these can greatly ease the transition from old to new economy and encourage creative economic development. And yet, ironically, each of these organizations working toward sustainable economic resources in a new economy has seen its own sustainability called into question, as financing has been reduced nearly to nonexistence.

\section{UTILIZATION OF INTELLECTUAL PROPERTY (IP) LAW}

The third thing that we can do to promote the role of intellectual property in an economy that is transitioning from old to new is to promote the use of IP through education and training in (and use of) IP laws. As an asset with its value in content and information, by definition intellectual property is not tied to a particular geography. Rather, uniquely, where commercial assets all too frequently once stopped short in the face of a mountain, intellectual property assets can flow through the valleys as rivers, whether to a distant manufacturer or licensee, equity partner or distributor. A global information economy creates mountain passes while leaving the beauty of the mountains intact.

Intellectual property protection, importantly, however, is something that is crucial to consider on the front end of any venture, for if certain steps are not taken, key rights can be lost. Trademark rights, for example, depend upon the use of a mark that does not infringe on another's rights, which requires forethought in planning (sometimes more thought than a marketing department would like). ${ }^{67}$ Patent protection relies on specific public disclosure provisions, for example, which, if not followed, will result in a complete lack of protection for the applicant. ${ }^{68}$

History is rife with examples of intellectual property successes and failures. There are at least three people who claimed to have invented the telephone, for example, and yet the one who reaped all of the benefits, in both dollars and the annals of history, Alexander Graham Bell, was the one who was granted a US patent. Elisha Gray also claimed to have invented the telephone. ${ }^{69}$ Elisha Gray had been in competition with Bell to invent a harmonic telegraph. ${ }^{70}$ Gray developed the capability to transmit multiple sounds through a telegraph in 1874, but not speech. ${ }^{71}$ In February, 1876, 
Gray inscribed the drawings for the telephone in his notebook; a few days later, his lawyer filed a patent caveat with the United States Patent Office. ${ }^{72}$ The same day, Bell's lawyer filed a patent application for the harmonic telegraph, including speech. ${ }^{73}$

Beyond those basic facts, there are multiple theories attesting to what happened next. One theory claims that Bell paid the patent examiner US\$100 to obtain access to Gray's specifications, which taught Bell how to make the telephone. ${ }^{74}$ This theory is supported as well by an affidavit submitted years later by the patent examiner. ${ }^{75}$ Another theory claims that Gray's lawyers advised him to withdraw his patent caveat because Bell's application had been filed first. ${ }^{76}$ These theories explore a possible conflict of interest between Gray and his attorney, William Baldwin, who was on the payroll of Bell Telephone Company while representing Gray in an action against them. ${ }^{77}$

Largely outside the controversy between Bell and Gray, and thus creating a sort of Venn diagram of invention, was the Italian immigrant Antonio Meucci, who Congress acknowledged in 2002 as the true inventor of the first electromagnetic telephone. ${ }^{78}$ Meucci had developed a system to communicate from the second-floor bedroom of his house, where his wife lay paralysed, to his basement laboratory. ${ }^{79}$ In fact, between the years 1856 and 1870 , Meucci is thought to have developed multiple telephones. ${ }^{80}$ For whatever reason, however, Meucci did not obtain patent protection on his invention. Some people posit that he was unable to obtain financing for the project. ${ }^{81}$ Others theorize that he was unable to obtain patent protection because of prototypes and documents that had been lost when he worked in a lab with Alexander Graham Bell. ${ }^{82}$ And still others assert that Congress erred in even giving credit to Meucci for the invention of the first electromagnetic telephone.$^{83}$ Whatever the reason, he was entirely excluded from both credit for the invention and its profits thereafter. Because Bell was given the intellectual property rights over the invention, he alone was able to capitalize on it. The role of intellectual property law in innovation, entrepreneurship and the growth of industry is not to be underestimated.

Groundbreaking technological developments, such as the telephone, are valuable intellectual property resources, but all intellectual property resources that have value are not necessarily groundbreaking technological developments. And while a misunderstanding of, or disregard for, intellectual property law can prevent the protection of valuable resources in the marketplace, intellectual property law can serve as a useful tool in creating and developing those valuable resources. Intellectual property is found everywhere, and the proper exploitation and use of it can support economic development in a multitude of ways, ways not limited to groundbreaking inventions. The Ziegenfelder Company serves as an excellent 
example of this principle. The Ziegenfelder Company has taken a very common product, and, through the use of intellectual property, has grown into a very successful organization. The company began 140 years ago as a confectionary. ${ }^{84}$ In 1989 , the company decided to refine its mission, and to focus on the manufacturing and selling of frozen twin-pops ${ }^{85}$ Now, frozen twin-pops, made essentially of water, sugar and flavoring, are not exactly what one would think of as an innovation, no matter how tasty they happened to be. (Perhaps Lloyd Benson would look at a twin-pop and say, 'I know innovation; and you are no innovation.') But the Ziegenfelder Company packaged these twin-pops in a unique way, developing a form of trade dress, in what they call the Rainbow Array. ${ }^{86}$ The Rainbow Array consists of twin-pops arranged head to foot, in a clear plastic bag, in the colors of the rainbow. The Rainbow Array serves as a source identifier for the Ziegenfelder twin-pops, and this distinctive trade dress has helped them to grow from a small-town, local confectionary to a company that manufactures and sells millions of twin-pops a year across the country. ${ }^{87}$

\section{CONCLUSION}

Old and new economies are not entirely divorced from one another, and it is important to keep that in mind. The professional and substantive skills that people have developed in industry and manufacturing can further contribute to their success in new economy endeavors. Detroit is an area of the country that exemplifies, perhaps, the potential for intellectual property to play a central role in the transition from old to new economy. Individuals in Detroit are searching for new economic opportunities in light of the difficulties in the auto industry. New economy firms that are expanding see an opportunity to hire workers in Detroit. In a segment on National Public Radio, one high-tech executive was asked in an interview why he split his workforce between India and Michigan, rather than hiring the less expensive labor exclusively in India ${ }^{88} \mathrm{He}$ responded that 'the Michigan workforce, which has significant experience in automotive and manufacturing industry, understands how things work. ${ }^{89}$ In fact, this quality has recently attracted venture capitalists to Detroit, interested in investing in minority-owned firms that had received solid business experience by the 'Big Three' automakers (Ford, Chrysler and General Motors). The story coincidentally mentioned the development of intellectual property that is taking place in a skilled workforce as Detroit's car industry is drying up - ways that former autoworkers are also finding ways to participate in new economy endeavours. ${ }^{90}$ Former auto subcontractor Larry Smith, for example, a first-time entrepreneur, has invented a system that 
enables an individual to view multiple security cameras on a mobile device, which works anywhere there is a cell phone signal. ${ }^{91}$

The development and exploitation of intellectual property, and participation in the global information economy, are not dependent upon geography. It can take place from anywhere, from the inside of an empty factory in Detroit, to a small country road, nestled between the rhododendron and the river. From the R\&D lab at a university, to a barren plain in New Mexico. To move from coal to content, we must foster a dynamic and profitable environment for entrepreneurship, through a supportive and robust university community, through state legislation and institutional support and through effective utilization of intellectual property laws. Intellectual property and technology can be used in transitional economies to create meaningful opportunities for young people to live and to work in their communities, to make efficient use of their own resources. This issue spans art and science, business and industry, culture and environment. Twin-pops and telephones. Intellectual property can help people use traditional resources in the new economy - the art, the music, the know-how - and to cultivate human knowledge and creation in a manner that benefits these communities across the country. This is the American story, too - to create wealth from within. To 'Will Work'.

\section{ACKNOWLEDGMENTS}

I would like to thank Shubha Ghosh and Robin Paul Malloy, as well as the other organizers and participants in the University of Wisconsin Law School's Creativity, Law and Entrepreneurship Conference held in April 2009. I also thank Rachel Dillard and Rebecca Quarles for their research assisstance. Finally, a huge thank you to my father who continues to be an inspiration to me with regard to these issues (and many others).

\section{NOTES}

1. Portions of this story first appeared in Megan Carpenter, Beware Politicians Who Don't Respect Mountain Values, Culture, The Charleston Gazette July 2, 2006.

2. See West Virginia Community Impact, State by State Information, available at http://walmartstores.com/FactsNews/StateByState/State.aspx?st=WV (accessed Sept. 26, 2009); see also West Virginia Mining Statistics, West Virginia Office of Miners' Health, Safety, and Training, available at http://www.wvminesafety.org/STATS.HTM (accessed Sept. 26, 2009).

3. Michael Shnayerson, The Rape of Appalachia,VANITY FAIR, available at: http://www. vanityfair.com/politics/features/2006/05/appalachia200605 (May 1, 2006) (accessed Sept. 19, 2009). 
4. See http://www.nationalatlas.gov/articles/people/a_age2000.html (accessed Sept. 20, 2009).

5. See, e.g., A. Greenspan, (Feb. 27, 2004), Intellectual Property Rights, Remarks at the Stanford Institute for Economic Policy Research Economic Summit, available at http:// www.federalreserve.gov/Boarddocs/Speeches/2004/200402272/default.htm (accessed Dec. 7, 2010).

6. Morrill Act of 1862 (7 U.S.C. $\S 301$ et seq.); Morrill Act of 1890 (7 U.S.C. $\S 321$ et seq.) (granting federal land to states for use to support the development of land-grant universities).

7. Hatch Act of 1887 (7 U.S.C. \$ 361a et seq.) (allocating federal funds to states for use by land-grant colleges toward the establishment of agricultural experiment stations and the advancement of agricultural technology).

8. Adams Act of 1906 (34 Stat. 63) (supporting agricultural experiment stations in landgrant educational institutions).

9. Smith-Lever Act of 1914 (7 U.S.C. $\$ 343$ et seq.) (establishing cooperative extension programs in conjunction with land-grant universities).

10. Irwin Feller, Government-University Partnerships, 6-32, 13 in ECONOMIC DeVELOPMENT THROUGH ENTREPRENEURSHIP (Scott Shane, ed. 2005).

11. Id.

12. Id.

13. Id.

14. Id. at 16 .

15. Bayh-Dole Act of 1980 (35 U.S.C. $§ 200$ ) (also known as the University and Small Business Patent and Procedure Act of 1980).

16. Lawrence Rudolph, Overview of Federal Technology Transfer, Franklin Pierce Law Center, available at http:// www.fplc.edu/risk/vol5/spring/rudolph.hlan (May 1, 1998) (accessed Oct. 2, 2009).

17. Stevenson-Wydler Technology Innovation Act of 1980 (15 U.S.C. $§ 3701$ et seq.).

18. Id.

19. Id.

20. National Cooperation Research and Production Act of 1993 (15 U.S.C. $\S 4301-06$ ).

21. Omnibus Foreign Trade and Competitiveness Act of 1988 (19 U.S.C. $\$ 2905$ (a)).

22. ScotT Shane, Government Policies to Encourage Economic Development Through Entrepreneurship: The Case of Technology Transfer, in ECONOMIC DeVELOPMENT THROUGH ENTREPRENEURSHIP 33-49, 43 (Scott Shane, ed. 2005).

23. Id.

24. Id.

25. Id.

26. Id. at 34 .

27. Lori Pressman, Association of University Technology Managers (AUTM), AUTM Licensing Survey: FY 1999. (1999).

28. SHANE, supra note 22 , at 34 .

29. Id. at 35 .

30. MIT Sloan School of Management, Entrepreneurial Impact: The Role of MIT, 6 (Feb. 2009), available at http://entrepreneurship.mit.edu/Downloads/Entrepreneurial_ Impact_The_Role_of_MIT.pdf (last visited Oct. 2, 2009).

31. Id. at 5 .

32. Id. (stating that 'a less conservative direct extrapolation of the underlying survey data boosts the numbers to 25800 currently active companies founded by MIT alumni that employ about 3.3 million people and generate annual world sales of \$2 trillion, producing the equivalent of the eleventh-largest economy in the world.')

33. Shane, supra note 22 , at 37 .

34. T.S. Eliot, The Love Song of J. Alfred Prufrock, in PRUFROCK AND OTHER OBSERVATIONS (1917):

Time for you and time for me, 
And time yet for a hundred indecisions,

And for a hundred visions and revisions,

Before the taking of a toast and tea.

35. There are many historical accounts detailing the history of the development of the personal computer, including, inter alia, Martha Kendall, Steve WozniaK, InVEnTor of

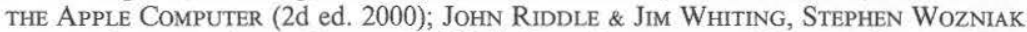
and the Story of Apple Computer (2001); Paul Freiberger \& Michael Swaine, Fire in the Valley: The Making of the Personal Computer (2d ed. 1999). In addition, there are many accounts of the history of Apple, Inc., available online, including, inter alia, www.apple-history.com, www.theapplemuseum.com, and http://apple2history. org.

36. Inventor of the Week: The Personal Computer, April 2007, http://web.mit.edu/invent/ iow/apple.html (accessed Dec. 7, 2010).

37. Id.

38. Id.

39. U.S. Patent 4136359 (issued Jan. 23, 1979).

40. Ernst \& Young, Economic and Fiscal Impacts of the New Mexico Film Production Tax Credit, Prepared for the New Mexico State Film Office and State Investment Council (January 2009), at i.

41. Id.

42. Id.

43. Id.

44. Deena Kalai, Does a Little Go a Long Way? Texas Entertainment Industry Economic Incentives, 71 TEx. B.J. 734, 732-38.

45. Id. at 735; La. Rev. Stat. Ann. § 47:6007 (2005).

46. Kalai, supra note 44 , at 735.

47. Id. at 736 .

48. Texas Gov't Code Ann. $§ 485.024$ (2007).

49. Id.

50. Texas Gov't Code Ann. $§ 485.025$ (2007).

51. W.Va. Code $\S 11-13 \mathrm{x}-1$; Tony Rutherford, Incentive Brings New Movies to West Virginia, HuntingtonNews.net (March 27, 2009) (accessed Sept. 26, 2009); see also West Virginia Film Office, http://www.wvfilm.com/incentives.htm (accessed Sept. 26, 2009).

52. Kalai, supra note 44, at 737 (citing Steve Persall, Florida's Budget Shortfall Could Curb TV, Film Productions Here, St. Petersburg Times (July 27, 2008).

53. Kalai, supra note 44 , at 736 .

54. Id.

55. Id.

56. Id.

57. Id.

58. Kalai, supra note 44 , at 736.

59. Id.

60. Id.

61. Id.

62. See generally http://www.wvhtf.org/ (accessed Sept. 26, 2009).

63. See, e.g., http://www.wvhtf.org/departments/rd/ (accessed Sept. 26, 2009).

64. See generally http://www.mountainmade.com (accessed Sept. 26, 2009).

65. See generally http://www.canaanvi.org/canaanvi_web/index.aspx (accessed Sept. 26, 2009).

66. See generally http://www.vandalia.org/about.htm (accessed Sept. 26, 2009).

67. See Lanham Act, 15 U.S.C. $\$ 1051$ et seq.

68. See U.S. Patent Act, 35 U.S.C. $\$ 1$ et seq.

69. See generally Evenson, A. Edward, The Telephone Patent Conspiracy of 1876: The Elisha Gray-Alexander Bell Controversy (North Carolina, 2000). 
70. Id. See also Seth Shulman, The Telephone Gambit: Chasing Alexander Graham BELL'S SECRET (2008).

71. SHulman, supra note 70 at 188.

72. Id at 37.

73. Peter Carlson, The Bell Telephone: Patent Nonsense, The Washington Post, Feb. 20, 2008, available at http:/www.washingtonpost.com/wp-dyn/content/article/2008/02/19/ AR2008021902596.html (accessed Dec. 7, 2010).

74. Id.

75. Id. See also Mr. Wilber Confesses, The Washington Post, May 22, 1886, at 1.

76. Evenson, supra note 69 , at 86

77. Id.

78. Carlson, supra note 73.

79. H.R. Res. 269, 107th Cong. (as passed by House of Rep., June 11, 2002).

80. See, e.g., Wikipedia, Antonio Meucci http://en.wikipedia.org/wiki/Antonio_Meucci (accessed Oct. 1, 2009).

81. H.R. Res. 269, 107th Cong. (as passed by House of Rep., June 11, 2002).

82. Id.

83. Gersh Kuntzman, Ring of Truth, 2002 WLNR 8852633, Nov. 18, 2002 (Pg. Unavail. Online).

84. Ziegenfelder Company, 'About Us', http://www.budgetsaver.com/news/aboutUs/ (accessed Sept. 26, 2009).

85. Id.

86. Ziegenfelder Co. v. Dunkirk Ice Cream Co., 30 U.S.P.Q. $2 d 1604$ (N.D.W.V. 1993) (granting preliminary protection for trade dress consisting of packaging for popsicles).

87. Ziegenfelder Company, supra note 84.

88. Steve Inskeep, Venture Capitalists, Entrepreneurs Bet on Detroit, National Public Radio (Apr.23, 2009), available at http://www.npr.org/templates/story.php?storyid =103374643

89. Id. (accessed Dec. 7, 2010)

90. Id.

91. Id. 